\title{
Aktivitas enzim ligninolitik Pleurotus ostreatus pada media yang mengandung TKKS dan aplikasinya untuk dekolorisasi zat warna
}

\author{
Activity of ligninolytic enzyme of Pleurotus ostreatus on media containing OPEFB and their application for \\ dyes decolorization
}

Firda DIMAWARNITA*) \& TRI-PANJI

Pusat Penelitian Bioteknologi dan Bioindustri Indonesia, Jl Taman Kencana 1, Bogor 16151, Indonesia

Diterima tgl 25 Maret 2019/ disetujui tgl 30 April 2019

\begin{abstract}
Ligninolytic enzymes are known as extracellular enzymes produced by the white rot fungi class of basidiomycetes. One of the most well-known fungi of the white rot fungus is Pleurotus ostreatus. The aim of this study to calculate the activity of ligninolytic enzymes in the growth media of Pleurotus ostreatus and their application in decolorization of dye colour. The ligninolytic enzyme extract obtained was used to decolorize blue dyes (Methylene Blue) and red dyes (Congo Red). The highest laccase enzyme activity was in the first month of $0.35 \mathrm{U} / \mathrm{mL}$ with E1 media composition; the highest manganese peroxidase (MnP) enzyme activity was in the fourth month at $31.818 \mathrm{U} / \mathrm{mL}$ with E4 media composition; and the highest lignin peroxidase (LiP) enzyme activity was in the fifth month at $0.269 \mathrm{U} / \mathrm{mL}$ with E1 media composition. The enzyme extract obtained was then applied to decolorize red and blue dyes. Decolorization of dyes was measured using spectrophotometry with a blue wavelength of $470 \mathrm{~nm}$ and red $685 \mathrm{~nm}$. The highest reduction in decolorization of blue dye and red dye was 12 hours with concentration of enzyme addition of $0.5 \%$. Based on these results, ligninolytic enzymes potentially to be developed as bioactive agents for detergents.
\end{abstract}

[Keywords: decolorization, laccase, mangan peroxidase, lignin peroxidase, spectrofotometry]

\section{Abstrak}

Enzim ligninolitik dikenal sebagai enzim ekstraseluler yang dihasilkan oleh jamur pelapuk putih golongan basidiomycetes. Salah satu jamur dari golongan jamur pelapuk putih yang banyak dikenal adalah Pleurotus ostreatus. Penelitian ini bertujuan menghitung aktivitas enzim ligninolitik pada media pertumbuhan jamur tiram (Pleurotus ostreatus) dan aplikasinya dalam dekolorisasi zat warna. Ekstrak enzim ligninolitik yang didapatkan kemudian dimanfaatkan untuk dekolorisasi zat warna biru (Methylene Blue) dan merah (Congo
Red). Aktivitas enzim lakase tertinggi ada pada bulan pertama sebesar $0,35 \mathrm{U} / \mathrm{mL}$ dengan komposisi media E1; aktivitas enzim mangan peroksidase (MnP) tertinggi ada pada bulan keempat sebesar 31,818 U/mL dengan komposisi media E4; dan aktivitas enzim lignin peroksidase (LiP) tertinggi ada pada bulan kelima sebesar 0,269 U/mL dengan komposisi media E1. Ekstrak enzim yang didapat kemudian diaplikasikan untuk dekolorisasi zat warna merah dan biru. Dekolorisasi zat warna diukur menggunakan spektrofotometri dengan panjang gelombang biru pada $470 \mathrm{~nm}$ dan merah pada $685 \mathrm{~nm}$. Penurunan dekolorisasi zat warna biru dan zat warna merah tertinggi selama 12 jam dengan konsentraasi penambahan enzim sebesar 0,5\%. Berdasarkan hasil tersebut, enzim ligninolitik sangat potensial untuk dikembangkan sebagai agen bioaktif untuk deterjen.

[Kata kunci: dekolorisasi, lakase, mangan peroksidase, lignin peroksidase, spektrofotometri]

\section{Pendahuluan}

Industri tekstil saat ini mengalami peningkatan yang signifikan. Pesatnya perkembangan industri tekstil berkaitan dengan kebutuhan masyarakat di bidang fashion yang semakin meningkat. Sehingga memacu produksi zat warna yang lebih beragam untuk memenuhi kebutuhan pewarnaan berbagai jenis kain. Struktur kimia zat warna dimodifikasi agar lebih stabil dan tidak mudah terdegradasi (Cai et al., 2011). Selama proses pewarnaan pada industri tekstil, $10-15 \%$ zat warna tekstil yang digunakan terbuang bersama limbah industri. Hanya beberapa industri besar yang mampu mengolah limbahnya sebelum dibuang ke lingkungan. Sedangkan industri kecil dan menengah umumnya tidak memiliki instalasi pengolahan limbah yang baik (Kant, 2012). Limbah pewarna yang tidak diolah ini sangat berbahaya dan dapat merusak lingkungan karena bersifat toksik, karsinogenik dan mutagenik (Padey et al., 2007; Zeng et al., 2011). 
Beberapa metode dekolorisasi limbah pewarna kini telah banyak dikembangkan, seperti metode fisika-kimia antara lain adsorpsi, pengolahan kimia, dan pertukaran ion. Metode ini membutuhkan biaya yang tinggi dan setelah pengolahan akan menghasilkan jumlah lumpur yang sangat besar. Metode lainnya yaitu pengolahan secara biologis. Metode ini memiliki banyak kelebihan antara lain aman bagi lingkungan, biaya yang lebih efektif, serta lebih sedikit menghasilkan lumpur dibandingkan dengan metode fisika-kimia. Pengolahan limbah pewarna secara biologis ini sering disebut dengan biodekolorisasi yang memanfaatkan bakteri, jamur, yeast, dan alga karena kemampuannya untuk mendegradasi pewarna pada keadaan anaerobik maupun aerobik (Singh et al., 2015).

Pleurotus ostreatus atau yang lebih dikenal dengan nama jamur tiram merupakan salah satu jamur yang dapat dimakan (edible mushroom), bernilai jual, dan memiliki gizi yang cukup tinggi. Jamur tiram mengandung protein tinggi, mineral anorganik dan rendah lemak. Kadar protein pada jamur ini lebih tinggi dibandingkan sumber protein lain seperti kedelai atau kacang-kacangan (Mulyanto \& Ika, 2017). Jamur tiram termasuk golongan jamur pelapuk putih penghasil enzim ligninolitik dan ekstraseluler seperti Lignin Peroksidase (LiP), Mangan Peroksidase (MnP), dan Lakase (Gorska et al, 2014). Jamur pelapuk putih dapat mendegradasi senyawa organik kompleks melalui katalisis. Jamur juga memiliki kemampuan yang tinggi dan efisien dalam beradaptasi dan menghilangkan senyawa aromatik serta mampu mendegradasi berbagai kontaminan organik dan anorganik (Sen et al., 2016). Enzim ligninolitik berperan dalam mendegradasi lignin pada substrat lignoselulosa. Enzim tersebut juga mampu mendegradasi berbagai senyawa rekalsitran dan polutan kompleks seperti pewarna (Zeng et al., 2011).

Pleurotus ostreatus dapat mendegradasi senyawa organik kompleks melalui katalisis dengan enzim ligninolitik ekstraseluler seperti lakase, MnP, dan LiP. Jamur juga menunjukkan kemampuan yang tinggi dalam beradaptasi dan efisien dalam menghilangkan senyawa aromatik serta mampu mendegradasi senyawa organik dan anorganik kontaminan (Sen et al., 2016). Enzim ligninolitik berperan dalam mendegradasi lignin pada substrat lignoselulosa. Enzim tersebut juga mampu mendegradasi berbagai senyawa rekalsitran dan polutan kompleks seperti pewarna (Zeng et al., 2011). Pleurotus ostreatus dapat tumbuh pada berbagai jenis limbah pertanian yang mengandung lignoselulosa seperti jerami, tandan kosong kelapa sawit (TKKS), serbuk gergaji, dan lainnya (Luz et al., 2012; Saskiawan, 2016; Sharma et al., 2013). TKKS merupakan salah satu limbah perkebunan yang keberadaannya melimpah karena areal perkebunan sawit di Indonesia yang cukup luas.

Luas areal perkebunan kelapa sawit setiap tahun mengalami peningkatan. Hal ini diikuti dengan peningkatan jumlah pelepah kelapa sawit dan tandan kosong kelapa sawit, produksi TKKS di Indonesia setiap tahunnya sekitar 9,5 juta ton. Total luas area kelapa sawit sebesar 12,3 juta $\mathrm{Ha}$ dan total produksinya sebesar 7 juta ton (Ditjenbun, 2017), yang artinya semakin banyak kelapa sawit maka hasil samping (limbah) dari kelapa sawit itu sendiri juga semakin banyak. TKKS merupakan limbah pabrik kelapa sawit (PKS) yang belum dimanfaatkan secara optimal. TKKS memiliki kandungan serat berupa lignin sekitar $17-83 \%$, selulosa sekitar $41-65 \%$, serta hemiselulosa (1783\%) (Dimawarnita \& Tri Panji., 2018). Kandungan TKKS tersebut dapat dimanfaatkan menjadi media pertumbuhan Pleurotus ostreatus.

Enzim lakase merupakan enzim yang dapat mereduksi oksigen menjadi air melalui reaksi oksidasi dan reduksi sekaligus melalui mediator (Christopher et al., 2014). Enzim lakase bekerja pada beberapa substrat utamanya senyawa fenolik dan hal itu menjadi salah satu keunggulan enzim ini. Pemanfaatan enzim ligninolitik antara lain, untuk mendegradasi lignin dan antioksidan senyawa dari guaiakol (Asgher et al., 2014). Enzim ligninolitik, khususnya lakase juga digunakan sebagai bleaching agent pada proses biodeglignifikasi pada pulp industri kertas (Virk et al., 2012). Enzim lakase adalah sekelompok enzim yang dihasilkan oleh jamur pelapuk putih (white rot fungi) secara ekstraseluler (Manavalan et al., 2015). Enzim lakase mampu mendegradasi lignin pada tumbuhan, enzim pendegradasi lignin (lignolitik) terdiri dari lakase (polifenol oksidase), lignin peroksidase ( $\mathrm{LiP}$ ) dan mangan peroksidase $(\mathrm{MnP})$, ketiganya merupakan multi enzim ekstraseluler yang berperan dalam proses depolimerisasi lignin (Sanchez, 2010).

Enzim ligninolitik merupakan enzim yang banyak mengandung tembaga oksidase dan mempunyai kemampuan untuk mengoksidasi senyawa fenol. Lakase mengkonversi senyawa fenol menjadi kuinin radikal dengan bantuan oksigen dan kemudian mengubahnya menjadi kuinon. Proses konversi ini juga menghasilkan beberapa substrat sampingan yang bermanfaat dalam proses degradasi. Lakase selain berperan dalam degradasi lignin, juga berperan dalam proses pigmentasi, pembentukan badan buah, dan sporulasi pada Jamur Pelapuk Putih (Wang et al., 2015). Enzim LiP yang dihasilkan oleh jamur mempunyai peluang besar untuk diaplikasikan pada bidang industri terutama industri pulp dan kertas (Savadevan \& Misra, 2013). Enzim LiP juga berperan dalam mendegradasi polutan seperti pewarna yang dihasilkan oleh industri tekstil (Valencia \& Meitiniarti, 2017). 
Penelitian mengenai aktivitas enzim ligninolitik pada Pleurotus ostreatus telah dilakukan diantaranya menggunakan berbagai macam media sebagai substrat pertumbuhan jamur, seperti bamboo sawdust sebagai media Pleurotus ostreatus (Yamauchi et al., 2018); sludge kertas sebagai media pertumbuhan P.ostreatus (Hong et al., 2015); serbuk gergaji pohon pinus sebagai media tumbuh Pleurotus sajor-caju (Ma et al., 2016); limbah kulit kopi dan kulit kayu putih sebagai media tumbuh Pleurotus ostreatus (Luz et al., 2012); TKKS sebagai media pertumbuhan Pleurotus ostreatus (Marlina et al., 2015). Tujuan penelitian ini adalah menghitung aktivitas enzim ligninolitik pada media pertumbuhan jamur tiram (Pleurotus ostreatus) dan aplikasinya dalam dekolorisasi zat warna. Aktivitas enzim ligninolitik diambil setiap bulan pada setiap variasi media yang dilakukan, kemudian aktivitas enzim terbaik diaplikasikan untuk dekolorisasi zat warna merah dan biru. Penghitungan absorbansi menggunakan AAS (Atomic Absorption Spectroscopy) pada panjang gelombang $470 \mathrm{~nm}$ dan $685 \mathrm{~nm}$.

\section{Bahan dan Metode}

\section{Bahan}

Tandan kosong kepala sawit (TKKS) diperoleh dari perkebunan kelapa sawit PTPN VIII Kertajaya, Banten. Pretreatment TKKS sebelum digunakan sebagai media jamur tiram adalah pencacahan, pencucian, dan pengeringan. TKKS dicacah hingga berukuran 1-2 $\mathrm{cm}$ kemudian dicuci untuk menghilangkan kotoran yang terbawa dan dikeringkan. Adapun bahan-bahan lain yang diperlukan, yaitu serbuk gergaji, $\mathrm{CaCO}_{3}$, dedak, Triple Super Phosphat (TSP), dan isolat jamur $P$. ostreatus. Pengukuran aktivitas enzim lakase berdasarkan metode Buswell et al. (1995); pengukuran aktivitas enzim $\mathrm{MnP}$ berdasarkan metode Buswell et al. (1995); dan pengukuran aktivitas enzim LiP berdasarkan metode Tien \& Kirk (1984). Dekolorsasi zat warna menggunakan material amobil berupa zeolit dan pewarnaan untuk dekolorisasi zat warna menggunakan Congo Red dan Direct Blue.

Pembuatan media pertumbuhan jamur tiram (Pleurotus ostreatus)

Pada penelitian ini, TKKS digunakan sebagai campuran pada media pertumbuhan jamur tiram sebagai sumber lignoselulosa yang berasal dari limbah perkebunan. TKKS divariasikan pada media pertumbuhan jamur tiram. Selain TKKS, media pertumbuhan juga memerlukan bahan baku lainnya untuk memenuhi kebutuhan nutrisi jamur. Variasi komposisi media pertumbuhan jamur terdapat pada Tabel 1 .

TKKS kering yang sudah dicacah, kemudian dicampur dengan bahan lain untuk membuat media pertumbuhan jamur (baglog). Campuran media disiram air sampai dengan kadar air 50-60\% (b/v) dan $\mathrm{pH} 5-6$, didiamkan semalaman agar bahan baku benar-benar tercampur secara homogen. Adapun bahan baku lainnya untuk pertumbuhan jamur tiram tertera pada Tabel 2. Campuran media dimasukkan kedalam plastik baglog dan disterilisasi menggunakan autoklaf selama 1 jam, suhu $121^{\circ} \mathrm{C}$, dan tekanan $1 \mathrm{~atm}$.

Baglog yang telah steril diinokulasikan dengan bibit jamur tiram sebanyak 1\% (b/b). Isolat jamur tiram (F2) merupakan isolat Pleurotus ostreatus yang ditumbuhkan pada media mengandung menir 98\% (b/b) dan dedak 2\% (b/b). Baglog yang telah diinokulasi selanjutnya diinkubasi pada suhu 23$25^{\circ} \mathrm{C}$. Baglog dibiarkan tertutup sampai miselium memenuhi baglog. Miselium akan memenuhi baglog selama 35 hari, kemudian tutup baglog dibuka untuk mempermudah penyiraman. Penyiraman dilakukan sebanyak 3 kali dalam sehari untuk menjaga kelembaban baglog sehingga fruiting body jamur tiram tumbuh (kelembaban dijaga pada 50-60\%). Satu siklus penanaman jamur tiram berlangsung selama 5 bulan. Aktivitas enzim ligninolitik diamati setiap bulan untuk mendapatkan aktivitas enzim optimal. Aktivitas enzim tertinggi diaplikasikan untuk biobleaching zat warna. Pada setiap perlakuan dilakukan sebanyak 3 ulangan.

\section{Perhitungan aktivitas enzim ligninolitik}

Aktivitas enzim ligninolitik diukur tiap bulan pada baglog jamur selama 5 bulan. Pengambilan sampel dilakukan pada bagian atas, tengah dan bawah baglog. Pemanenan filtrat enzim dilakukan dengan menggunakan sentrifuse $9000 \mathrm{rpm}, 15$ menit. Supernatan (filtrat) digunakan sebagai sumber enzim. Baglog yang berbentuk padatan dapat dihaluskan sehingga ukurannya seragam. Ukuran baglog dihaluskan sampai 70-80 mesh.

Tabel 1. Variasi komposisi media pertumbuhan jamur tiram.

Table 1. Composition variation of growth media of oyster mushroom.

\begin{tabular}{lc}
\hline Kode & TKKS : serbuk gergaji (\%) \\
Code & OPEFB : sawdust (\%) \\
\hline E1 & $25: 75$ \\
E2 & $50: 50$ \\
E3 & $75: 25$ \\
E4 & $0: 100$ \\
\hline
\end{tabular}

Tabel 2. Komposisi media pertumbuhan jamur tiram.

Table 2. Media composition for oyster mushroom growth.

\begin{tabular}{lc}
\hline Komposisi & Berat \\
Composition & Weight $(\%)$ \\
\hline Dedak/ Rice bran & 4,5 \\
$\mathrm{CaCO}_{3}$ & 1,34 \\
$\mathrm{TSP} /$ Triple Super Phosphate & 0,44 \\
\hline
\end{tabular}


Pengukuran aktivitas enzim lakase berdasarkan metode Buswell et al. (1995); aktivitas mangan peroksidase berdasarkan metode Buswell et al, (1995); dan aktivitas lignin peroksidase berdasarkan metode Tien \& Kirk (1984).

Perhitungan aktivitas enzim sebagai berikut:

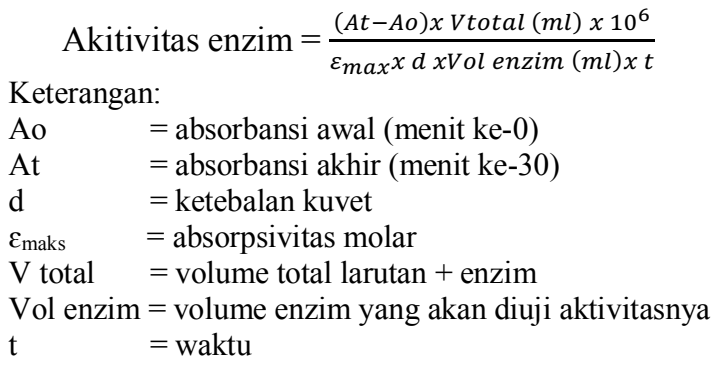

Konsentrasi pereaksi yang digunakan:
ABTS
: $36000 \mathrm{M}^{-1} \mathrm{~cm}^{-1}$
Guaiacol
: $12100 \mathrm{M}^{-1} \mathrm{~cm}^{-1}$
Veratril alkohol$$
\text { : } 9300 \mathrm{M}^{-1} \mathrm{~cm}^{-1}
$$

Aplikasi enzim ligninolitik untuk penghilangan zat warna

Aktivitas enzim ligninolitik yang tertinggi (pada umur baglog 4-5 bulan) kemudian diaplikasikan untuk dekolorisasi zat warna. Dalam hal ini zat warna yang digunakan adalah Congo Red dan Methylene Blue. Ekstrak kasar enzim ligninolitik di amobilisasi dengan zeolit sebagai material amobil. Zeolit serbuk sebanyak 1gr direndam dalam larutan enzim dengan konsentrasi $0,5 \% ; 1 \% ; 1,5 \% ; 2 \%$. Kemudian dikeringkan suhu ruang dan diaplikasikan pada zat warna dengan variasi waktu. Setiap proses dekolorisasi diukur absorbansinya pada panjang gelombang maksimal $470 \mathrm{~nm}$ Methylene Blue (Gomes et al., 2009), dan $685 \mathrm{~nm}$ Congo Red (Fatimah et al., 2010). Efisiensi dekolorisasi dapat dihitung melalui persamaan:

$$
\% \text { dekolorisasi }=\frac{I-F}{I} \times 100
$$

Keterangan: $\mathrm{I}=$ absorbansi awal dan $\mathrm{F}=$ absorbansi pada media terdekolorisasi

\section{Hasil dan Pembahasan}

\section{Aktivitas enzim Lakase}

Variasi media (E1, E2, E3, dan E4) yang digunakan untuk menumbuhkan Pleurotus ostreatus diambil sampel setiap bulannya untuk dihitung aktivitas enzim ligninolitiknya. Aktivitas enzim lakase tertinggi terdapat pada bulan pertama dengan komposisi media 25\% TKKS dan $75 \%$ serbuk gergaji (E1) dan aktivitasnya sebesar 0,35 $\mathrm{U} / \mathrm{mL}$ (Gambar 1). Hal tersebut karena sumber karbon dan nitrogen pada media masih cukup tinggi pada bulan pertama, sehingga aktivitas lakase pun juga tinggi, karena untuk memproduksi lakase dipengaruhi oleh faktor nutrisi yaitu tersedianya sumber karbon dan nitrogen (Majeau et al., 2010). Pertumbuhan tubuh buah pada bulan pertama belum optimal, Pleurotus ostreatus masih berada pada fase primordia (Dimawarnita \& Urip, 2017). Aktivitas tertinggi enzim lakase ada pada fase primordia dan miselium. Produksi enzim lakase dipengaruhi oleh faktor ketersediaan nutrisi seperti karbon dan nitrogen, konsentrasi dan rasio keduanya serta faktor lainnya seperti sifat dan konsentrasi induser (Majeau et al., 2010). Kemudian disusul pada bulan kelima yaitu berkisar $0,234 \mathrm{U} / \mathrm{mL}$ pada $\mathrm{E} 3$, namun tidak setinggi pada bulan pertama. Aktivitas enzim terendah ada pada bulan ketiga, hal tersebut dikarenakan pada bulan ketiga merupakan puncak dari pertumbuhan Pleurotus ostreatus. Hal ini sejalan dengan hasil yang didapat oleh Elisashvili (2003) yang menumbuhkan Pleurotus sajor-caju pada limbah agroindustri. Hasilnya, Pleurotus sajor-caju mengalami penurunan aktivitas lakase ketika mencapai fase fruiting body, dan aktivitas lakase meningkat saat fase miselium dan primordia. Pertumbuhan tubuh buah jamur tiram menyebabkan aktivitas enzim lakase berkurang karena nutrisi yang ada pada media digunakan jamur untuk pertumbuhan tubuh buahnya (Elisashvili et al., 2015).

Enzim lakase memiliki kemampuan dapat mengoksidasi poliamina, aminofenol, lignin, aril diamina, beberapa ion anorganik, dan mengurangi toksisitas beberapa polisiklik aromatik hidrokarbon (PAH) (Pozdnyakova et al., 2004), pestisida organofosfor dan mengoksidasi zat pewarna (Torres et al., 2003). Lakase dapat mengoksidasi berbagai molekul kompleks, beberapa diantaranya substrat untuk tirosinase monofenol monooksigenase. Sejauh ini, sekitar seratus senyawa telah diidentifikasi dapat menjadi substrat untuk jamur penghasil enzim lakase (Giardina et al., 2010).

\section{Aktivitas enzim Mangan Peroksidase (MnP)}

Salah satu enzim ligninolitik adalah enzim mangan peroksidase (MnP). Berdasarkan Gambar 2 menunjukkan bahwa aktivitas tertinggi enzim $\mathrm{MnP}$ terdapat pada bulan ke 4 yaitu sebesar 31,818 $\mathrm{U} / \mathrm{mL}$ pada komposisi media E4. Sedangkan aktivitas MnP terendah ada pada bulan kedua sebesar 2,755 U/mL pada komposisi media E4. Pada Gambar 2 terlihat bahwa grafik antar variasi media tidak terlalu berbeda nyata. Pada variasi media E1 sampai dengan E4 mengalami aktivitas tertinggi pada bulan ke 4 dan aktivitas terendah pada bulan kedua. Hal ini karena pada bulan-bulan awal pertumbuhan jamur Pleurotus ostreatus masih pada tahap miselium dan primordia. Kemudian pada bulan ke 3 dan ke 4 dimana pertumbuhan jamur sedang pada fase fruiting body, aktivitas enzim MnP ada pada aktivitas tertinggi. Aktivitas enzim MnP berkebalikan dengan enzim lakase. 


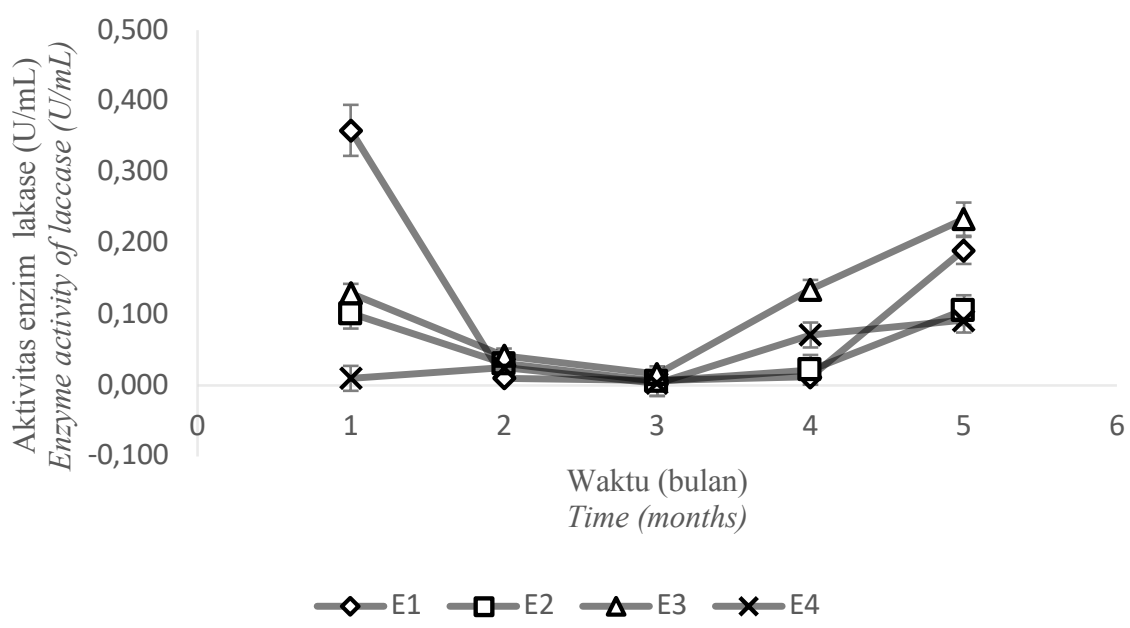

Gambar 1. Aktivitas enzim lakase pada berbagai variasi media pertumbuhan Pleurotus ostreatus. Figure 1. Activity of laccase enzyme on variation growth media of Pleurotus ostreatus.

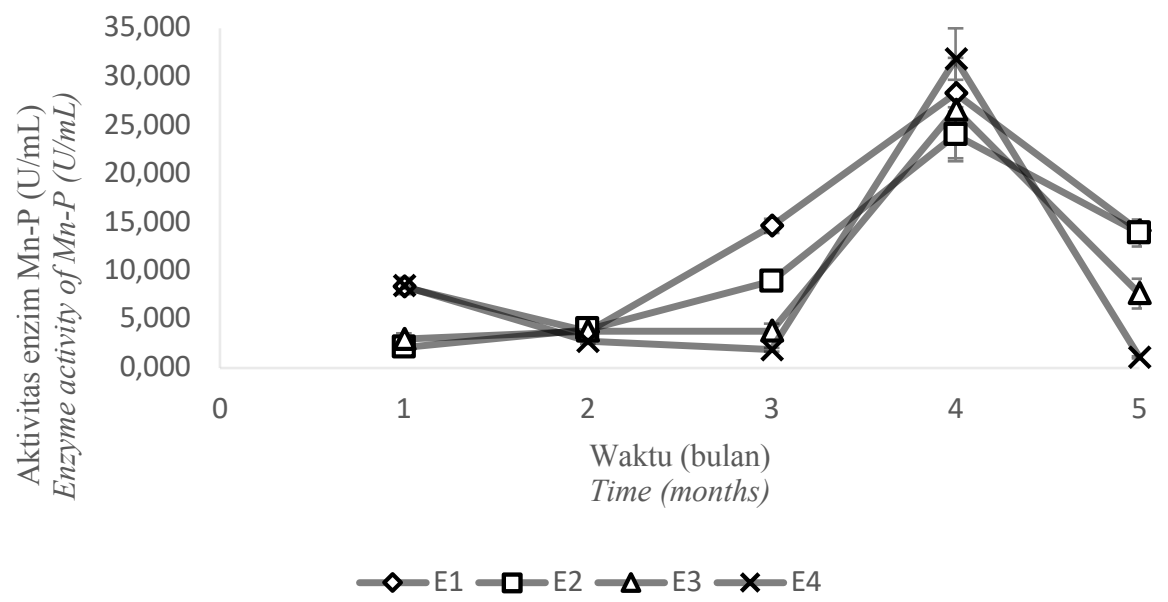

Gambar 2. Aktivitas enzim mangan peroksidase (MnP) pada berbagai variasi media pertumbuhan Pleurotus ostreatus.

Figure 2. Activity of mangan peroxidase $(\mathrm{MnP})$ enzyme on variation growth media of Pleurotus ostreatus.

Hal tersebut sejalan dengan penelitian yang dilakukan Luz et al. (2012) yang melakukan penelitian pada jamur Pleurotus pulmonarius, Pleurotus sajor-caju, dan L. edodes menunjukkan aktivitas MnP sangat rendah pada fase primordia dan miselium jamur. Peningkatan aktivitas MnP akan meningkat seiring dengan munculnya tubuh buah jamur. Aktvitas enzim ligninolitik erat kaitannya dengan perkembangan tubuh buah jamur dan kondisi fisiologis jamur. Namun, perbedaan aktivitas enzim lakase dan MnP dipengaruhi oleh spesies jamur dan substrat pertumbuhan (Kisoka et al., 2014).

\section{Aktivitas enzim Lignin Peroksidase (LiP)}

Aktivitas enzim LiP pada Gambar 3 menunjukkan bahwa aktivitas tertinggi terdapat pada variasi media E1 pada bulan ke 5 sebesar $0,269 \mathrm{U} / \mathrm{mL}$ dan aktivitas enzim LiP terendah terdapat pada bulan ketiga sebesar $0,036 \mathrm{U} / \mathrm{mL}$ pada variasi media E4. Hal ini membuktikan bahwa pleurotus ostreatus dapat tumbuh optimal dan menghasilkan aktifitas enzim LiP pada range waktu yang lama selama satu siklus penanaman jamur. Hal ini dapat dilihat bahwa pada bulan kelima (Gambar 3) grafik aktivitas enzim LiP masih terus mengalami peningkatan. Hasil tersebut sesuai dengan penelitian Gomes et al. (2009) dimana aktivitas LiP pada Lentinus sp. masih terus meningkat pada minggu kelima. Jamur yang digunakan adalah Lentinus strigellus; Lentinus sp.; dan Picnosporus sanguinerus. Hal ini berbeda jauh dengan aktivitas enzim MnP (Gambar 2) yang terlihat mulai mengalami penurunan aktivitas ketika bulan kelima. Aktivitas enzim LiP dipengaruhi oleh beberapa faktor, diantaranya pengaruh dari $\mathrm{H}_{2} \mathrm{O}_{2}$. LiP adalah enzim peroksida ekstraseluler yang mengoksidasi senyawa aromatik (phenolik dan non phenolik) dengan memindahkan 1 elektron menghasilkan fenoksi 
radikal dan kation radikal (Akhtar et al., 1997). Pengukuran aktifitas LiP menggunakan $\mathrm{H}_{2} \mathrm{O}_{2}$ sebagai reduktor yang akan mengoksidasi enzim pada keadaan awal dengan dua elektron membentuk senyawa intermediet 1 (Ilmi \& Kusywitasari, 2014).

Produksi enzim ligninolitik ekstraseluler sangat dipengaruhi oleh sifat dan jumlah nutrisi dalam substrat, khususnya nitrogen, dan elemen mikro (Buswell et al., 1995; Viswanath et al., 2014; Khelifi et al., 2009). Limbah pertanian seperti dedak, gandum, jerami, dan TKKS telah digunakan untuk meningkatkan produksi enzim ligninolitik dalam fermentasi cair dan fermentasi padat (Nadeem et al., 2014; Flores et al., 2010). Ketersediaan $\mathrm{N}$ dalam substrat juga menjadi faktor penentu aktivitas enzim ligninolitik. Pada beberapa spesies jamur, produksi enzim ligninolitik terhambat oleh konsentrasi $\mathrm{N}$ yang tinggi sementara pada spesies jamur lain, konsentrasi tinggi $\mathrm{N}$ justru merangsang aktivitas enzim ligninolitik (Mäkelä et al., 2013; Kenkebashvili et al., 2012; Levin et al., 2010; Purahong et al., 2014).

\section{Dekolorisasi zat warna biru}

Proses dekolorisasi zat warna dilakukan pada zat warna merah Congo Red dan zat warna biru Methylene Blue. Berdasarkan Gambar 4 terlihat bahwa penurunan terbanyak terjadi pada $0,5 \%$ enzim pada waktu 12 jam pertama. Methylene Blue mengandung senyawa triazyne yang merupakan salah satu senyawa yang dapat didegradasi oleh enzim ligninolitik. Dalam penelitian ini dapat dilihat hasil yang positif dan berpotensi untuk dikembangkan pada skala komersial. Zat warna biru relatif lebih mudah dioksidasi dibandingkan warna merah karena strukturnya yang tidak lebih kompleks dibandingkan struktur senyawa dari golongan -azo (Chacko \& Subramaniam, 2011). Penurunan intensitas warna paling cepat terjadi pada 12 jam pertama dan selanjutnya penurunan intensitas zat warna biru tidak terlalu banyak. Berdasarkan hasil tersebut, pemanfaatan enzim ligninolitik ini berpotensi diaplikasikan dalam industri deterjen. Enzim ligninolitik dapat digunakan sebagai bahan aktif deterjen karena potensinya sebagai penghilang warna yang spesifik. Penggunaan yang sedikit cukup bisa mendegradasi warna tertentu dalam waktu 12 jam pertama. Kinerja enzim secara umum efektif mulai dari waktu kontak selama 6 jam.

Hal ini sesuai dengan penelitian Gomes et al., 2009 yang menggunakan jamur Lentinus strigellus sebagai salah satu agen penghasil enzim ekstraseluler ligninolitik menghasilkan waktu optimum untuk penurunan zat warna biru selama 12 jam pertama. Kedepannya perlu dilakukan penelitian yang lebih mendalam untuk optimasi aplikasi enzim ligninolitik untuk mendegradasi zat warna.

\section{Persen dekolorisasi zat warna merah}

Dekolorisasi pada penelitian ini juga diaplikasikan pada zat warna merah Congo Red. Berdasarkan Gambar 5 dapat dilihat bahwa penurunan tertinggi pada proses dekolorisasi zat warna merah ada pada $0,5 \%$ konsentrasi enzim ligninolitik sama halnya dengan zat warna biru. Waktu yang optimum untuk dekolorisasi zat warna ini adalah 12 jam.

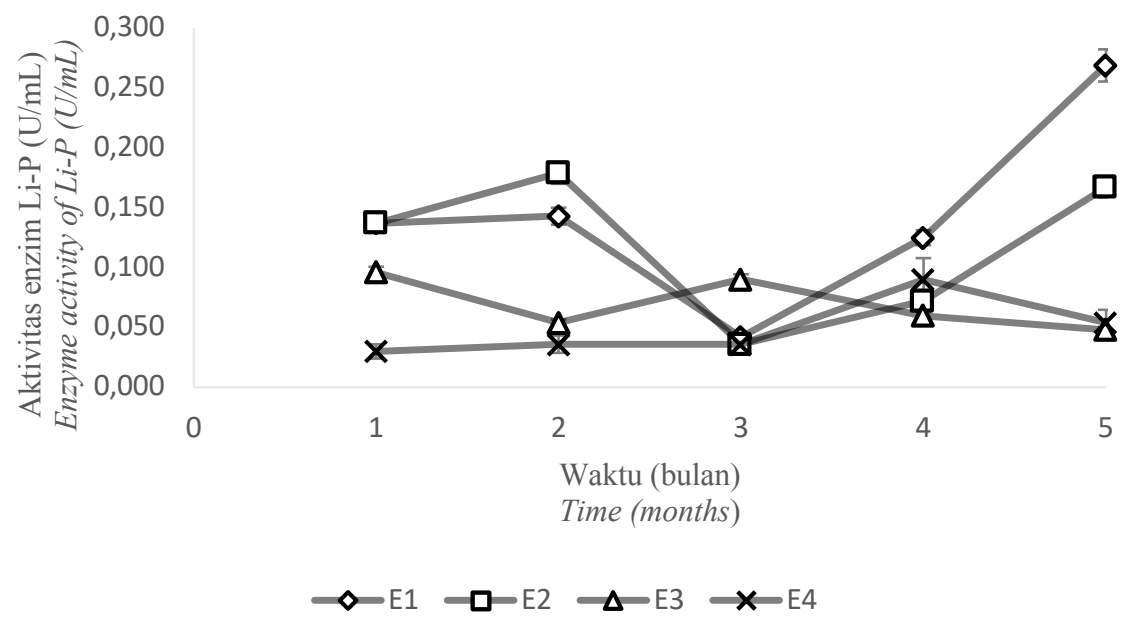

Gambar 3. Aktivitas enzim lignin peroksidase (LiP) pada berbagai variasi media pertumbuhan Pleurotus ostreatus. Figure 3. Activity of lignin peroxidase (LiP) enzyme on variation growth media of Pleurotus ostreatus. 

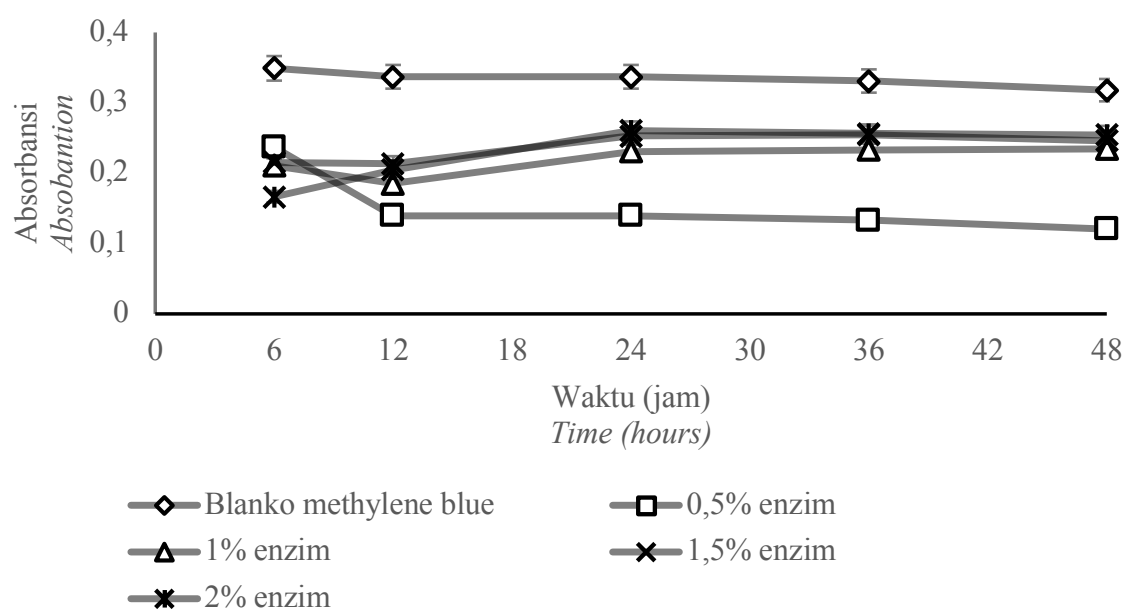

Gambar 4. Dekolorisasi zat warna biru menggunakan ekstrak enzim ligninolitik.

Figure 4. Decolorization of blue dye with ligninolytic enzyme extract.

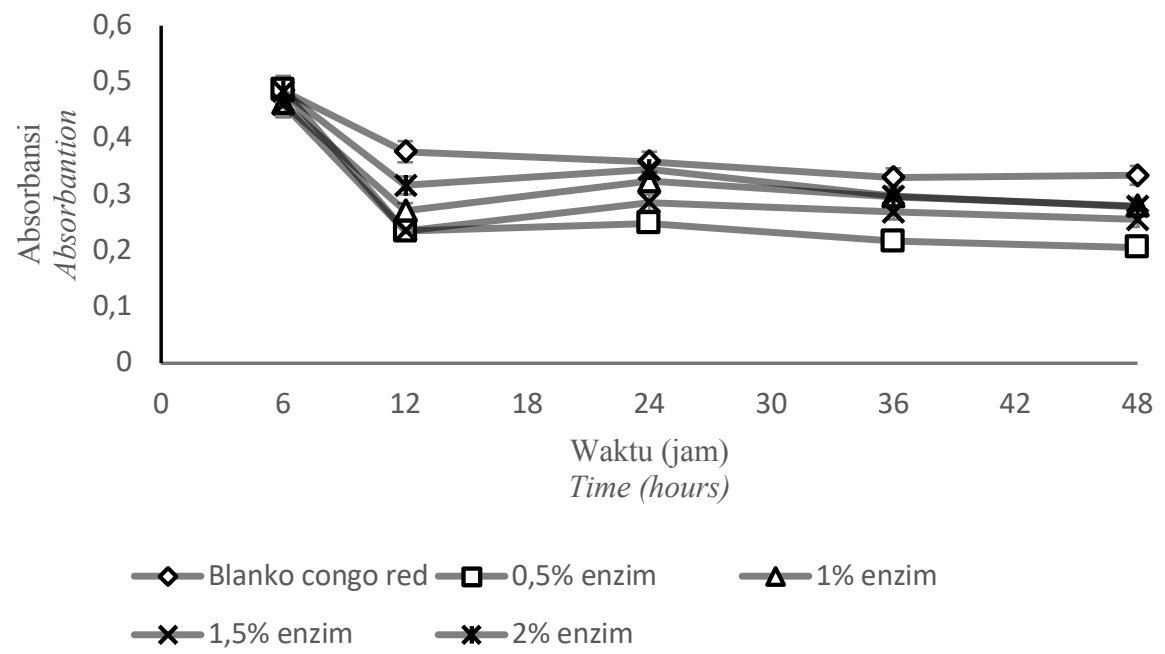

Gambar 5. Dekolorisasi zat warna merah menggunakan ekstrak enzim ligninolitik. Figure 5. Decolorization of red dye with ligninolytic enzyme extract.

Enzim yang berperan dalam dekolorisasi zat warna merah adalah enzim lakase. Lakase telah banyak dikenal sebagai pendegradasi zat warna golongan azo- (Saratale et al., 2011; Singh et al., 2015; Ashrafi et al., 2013). Lakase mengoksidase gugus phenolik pada zat warna phenolic azo, dengan memutuskan ikatan satu elektron phenoksi radikal yang diikuti dengan oksidasi menjadi ion karbonium. Proses degradasi senyawa azo- tidak semudah pada senyawa triazyne hal ini dikarenakan kompleksitas senyawa keduanya yang sangat berbeda. Pada proses dekolorisasi zat warna merah ini sama dengan sebelumnya, dimana konsentrasi enzim terendah $(0,5 \%)$ memberikan penuruanan dekolorisasi yang tinggi dibandingkan konsentrasi enzim yang lain, namun menurun pada jam berikutnya. Hal tersebut menunjukkan bahwa enzim ligninolitik yang diekstraksi dari media jamur berbahan TKKS ini potensial untuk dikembangkan lebih luas sebagai bahan aktif pada deterjen.

\section{Kesimpulan}

Enzim ligninolitik yang diekstraksi dari substrat media Pleurotus ostreatus yang mengandung tandan kosong kelapa sawit memiliki aktivitas tertinggi untuk lakase sebesar $0,35 \mathrm{U} / \mathrm{mL}$ pada bulan pertama dengan komposisi media E1; mangan peroksidase (MnP) sebesar 31,818 U/mL pada bulan keempat dengan komposisi media E4 ; dan lignin peroksidase (LiP) sebesar 0,269 $\mathrm{U} / \mathrm{mL}$ pada bulan kelima dengan komposisi media E1. Kemampuan enzim ligninolitik dalam dekolorisasi zat warna biru dan zat warna merah optimal pada penambahan konsentrasi enzim sebesar 0,5\% selama 12 jam. Kemampuan enzim ligninolitik sangat efektif dalam mendekolorisasi zat warna tertentu (Methylene Blue dan Congo Red). 


\section{Ucapan Terima kasih}

Kami ucapkan terima kasih kepada Ibu Ida Farida Sdri dan Yusdiana Putri Maulidya atas sumbangsihnya dalam penelitian ini. Dan juga pada Badan Pengelola Dana Perkebunan Kelapa Sawit (BPDPKS) tahun 2017-2019 yang telah membantu dalam hal pendanaan dalam penelitian ini sehingga dapat berjalan dengan lancar sesuai output yang dijanjikan.

\section{Daftar Pustaka}

Akhtar M, Blanchette R A \& Kirk T K (1997). Fungal delignification and biomechanical pulping of wood. In Biotechnology in the pulp and paper industry (pp. 159-195). Springer, Berlin, Heidelberg.

Asgher M, Shahid M, Kamal S \& Iqbal H M N (2014). Recent trends and valorization of immobilization strategies and ligninolytic enzymes by industrial biotechnology. Journal of Molecular Catalysis B: Enzymatic 101, 5666.

Ashrafi S D, Rezaei S, Forootanfar H, Mahvi A H \& Faramarzi M A (2013). The enzymatic decolorization and detoxification of synthetic dyes by the laccase from a soil-isolated ascomycete, Paraconiothyrium variabile. International Biodeterioration \& Biodegradation 85, 173-181.

Buswell JK, Cai YJ \& Chang ST (1995). Effect of nutrient nitrogen on manganese peroxidase and laccase production by Lentinula (Lentinus) edodes. FEMS Microbiol Lett 128, 81-88.

Cai Y J, Lin LN, Xia DS, Zeng QF \& Zhu H L (2011). Degradation of reactive brilliant red X$3 \mathrm{~B}$ dye by microwave electrodeless UV irradiation. CLEAN-Soil, Air, Water 39(1), 6873.

Chacko JT \& Subramaniam K (2011). Enzymatic degradation of azo dyes-a review. International Journal of Environmental Sciences 1(6), 1250-1260.

Christopher LP, Yao B \& Ji Y (2014). Lignin biodegradation with laccase-mediator systems. Frontiers in Energy Research 2, 1-13.

Dimawarnita F \& Tri Panji (2018). Sintesis karboksimetil selulosa dari sisa baglog jamur tiram (Pleurotus ostreatus). Jurnal Menara Perkebunan 86(2), 96-106.

Dimawarnita F \& Urip P (2017). Pemanfaatan tandan kosong kelapa sawit untuk produksi jamur tiram (Pleurotus sp.) dan enzim ligninase. Jurnal Mikologi Indonesia 1(2), 105-113.
Direktorat Jenderal Perkebunan (2017). Statitstik Perkebunan Indonesia 2015-2017: Kelapa Sawit. Direktorat Jenderal Perkebunan, Jakarta.

Elisashvili V, Chichua D, Kachlishvili E, Tsiklauri N \& Khardziani T (2003). Lignocellulolytic enzyme activity during growth and fruiting of the edible and medicinal mushroom Pleurotus ostreatus (Jacq.: Kumm.(Agaricomycetideae). International Journal of Medicinal Mushrooms 5(2).25-31.

Elisashvili V, Kachlishvili E \& Asatiani M D (2015). Shiitake medicinal mushroom, Lentinus edodes (higher Basidiomycetes) productivity and lignocellulolytic enzyme profiles during wheat straw and tree leaf bioconversion. International journal of medicinal mushrooms 17(1). 77-86.

Fatimah I, Sugiharto E, Wijaya K, Tahir I \& Kamalia K (2010). Titanium oxide dispersed on natural zeolite (TiO 2/Zeolite) and its application for congo red photodegradation. Indonesian Journal of Chemistry, 6(1), 38-42.

Flores C, Casasanero R, Trejo-Hernández M R, Galindo E \& Serrano-Carreón L (2010). Production of laccases by Pleurotus ostreatus in submerged fermentation in co-culture with Trichoderma viride.Journal of applied microbiology 108(3), 810-817.

Giardina P, Faraco V, Pezzella C, Piscitelli A, Vanhulle S \& Sannia G (2010). Laccases: a never-ending story. Cellular and Molecular Life Sciences 67(3), 369-385.

Gomes E, Aguiar A P, Carvalho C C, Bonfá M R B, Silva R D \& Boscolo M (2009). Ligninases production by Basidiomycetes strains on lignocellulosic agricultural residues and their application in the decolorization of synthetic dyes. Brazilian Journal of Microbiology 40(1), 31-39.

Gorska E B, Jankiewicz U, Dobrzynski J, Galazka A, Sitarek M, Gozdowski \& Kowalczyk (2014). Production of ligninolytic enzymes by cultures of white rot fungi. Pol J Microbiol 63(4), 4615 .

Hong Y, Dashtban M, Chen S, Song R \& Qin W (2015). Lignin in paper mill sludge is degraded by white-rot fungi in submerged fermentation. J Microb Biochem Technol 7, 177-181.

Ilmi IM \& ND Kuswytasari (2014). Aktifitas enzim lignin peroksidase oleh Gliomastix sp. T3. 7 pada limbah bonggol jagung dengan berbagai $\mathrm{pH}$ dan suhu. Jurnal Sains dan Seni ITS 2(1), E38-E42. 
Kant R (2012). Textile dyeing industry an environmental hazard. Natural science 4(1), 22-26.

Kenkebashvili N, Elisashvili V \& Wasser S P (2012). Effect of carbon, nitrogen sources, and copper concentration on the ligninolytic enzyme production by Coriolopsis gallica. Journal of waste conversion, Bioproducts and Biotechnology 1(2), 22-27.

Khelifi E, Ayed L, Bouallagui H, Touhami Y \& Hamdi M (2009). Effect of nitrogen and carbon sources on Indigo and Congo red decolourization by Aspergillus alliaceus strain 121C. Journal of Hazardous Materials 163(23), 1056-1062.

Kisoka F P, Mtui G Y S, Mshandete A M \& Kivaisi A K (2014). Ligninolytic enzymes activities of Pleurotus sapidus P969 during vegetative growth and fruit development on sugarcane residues-based substrates. The International Journal of Biotechnology 3(4), 58-71.

Levin L, Melignani E \& Ramos A M (2010). Effect of nitrogen sources and vitamins on ligninolytic enzyme production by some whiterot fungi. Dye decolorization by selected culture filtrates. Bioresource technology 101(12), 4554-4563.

Luz JMRD, Nunes MD, Paes SA, Torres DP, Silva MDCSD \& Kasuya MCM (2012). Lignocellulolytic enzyme production of Pleurotus ostreatus growth in agroindustrial wastes. Brazilian Journal

Microbiology, 43(4), 1508-1515.

Ma L, Lin Y Q, Yang C, Ying Z H \& Jiang X L (2016). Production of liquid spawn of an edible mushroom, Sparassis latifolia by submerged fermentation and mycelial growth on pine wood sawdust. Scientia horticulturae 209, 2230.

Majeau J A, Brar S K \& Tyagi R D (2010). Laccases for removal of recalcitrant and emerging pollutants. Bioresource technology, 101(7), 2331-2350.

Mäkelä M R, Lundell T, Hatakka A \& Hildén K (2013). Effect of copper, nutrient nitrogen, and wood-supplement on the production of ligninmodifying enzymes by the white-rot fungus Phlebia radiata. Fungal biology, 117(1), 62-70.

Manavalan T, Manavalan A \& Heese K (2015). Characterization of lignocellulolytic enzymes from white-rot fungi. Current microbiology, 70(4), 485-498.

Marlina, L., Sukotjo, S., \& Marsudi, S. (2015). Potential of oil palm empty fruit bunch (EFB) as media for oyster mushroom, Pleurotus ostreatus cultivation. Procedia Chemistry, 16, 427-431.

Mulyanto A \& Ika Oksi S (2017). Faktor-faktor yang mempengaruhi budidaya tiram putih dan upaya perbaikannya di desa kaliori kecamatan banyumas kabupaten banyumas provinsi jawa tengah. Bioscientiae 14 (1), 9-15.

Nadeem A, Baig S \& Sheikh N (2014). Mycotechnological production of laccase by Pleurotus ostreatus $\mathrm{P} 1$ and its inhibition study. J Anim Plant Sci 24(2), 492-502.

Pandey, A., Singh, P., \& Iyengar, L. (2007). Bacterial decolorization and degradation of azo dyes. International biodeterioration \& biodegradation, 59(2), 73-84.

Pozdnyakova NN, Rodakiewicz-Nowak J \& Turkovskaya OV (2004). Catalytic properties of yellow laccase from Pleurotus ostreatus D1. J Mol Catal B Enzym. 30, 19-24.

Purahong W, Kapturska D, Pecyna M J, Schulz E, Schloter M, Buscot F \& Krüger D (2014). Influence of different forest system management practices on leaf litter decomposition rates, nutrient dynamics and the activity of ligninolytic enzymes: a case study from Central European forests. PLoS One, 9(4), 19-37.

Sahadevan LDM \& Misra CS (2013). Ligninolytic enzymes for application in treatment of effluent from pulp and paper industries. Universal Journal of Environmental Research \& Technology, 3(1), 68-75.

Sánchez C (2010). Cultivation of Pleurotus ostreatus and other edible mushrooms. Appl Microbiol Biotechnol 85, 1321-1337.

Saratale R G, Saratale G D, Chang J S \& Govindwar S P (2011). Bacterial decolorization and degradation of azo dyes: a review. Journal of the Taiwan Institute of Chemical Engineers 42(1), 138-157.

Saskiawan I (2016). Penambahan inokulan mikroba selulolitik pada pengomposan jerami padi untuk media tanam jamur tiram putih (Pleurotus ostreatus). Jurnal Biologi Indonesia, 11(2), 187-193

Sen S K, Raut S, Bandyopadhyay P \& Raut S (2016). Fungal decolouration and degradation of azo dyes: a review. Fungal Biology Reviews, 30(3), 112-133.

Sharma S, Yadav R K P \& Pokhrel C P (2013). Growth and yield of oyster mushroom (Pleurotus ostreatus) on different substrates. Journal on New Biological Reports, 2(1), 03-08. 
Singh RL, Singh PK \& Singh RP (2015). Enzymatic decolorization and degradation of azo dyes-A review. International Biodeterioration \& Biodegradation, 104, 2131.

Tien M \& Kirk TK (1984). Lignin-degrading enzyme from Phanerochaete chrysosporium: purification, characterization, and catalytic properties of a unique H2O2-requiring oxygenase. Proceedings of the National Academy of Sciences, 81(8), 2280-2284.

Torres E, Bustos-Jaimes I \& Le Borgne S (2003). Potential use of oxidative enzymes for the detoxification of organic pollutants. Appl Catal B Environ 46, 1-15.

Valencia PE \& Meitiniarti VI (2017). Isolasi dan karakterisasi jamur ligninolitik serta perbandingan kemampuannya dalam biodelignifikasi. Scripta Biologica 4(3). 171175 .

Virk A P, Sharma P \& Capalash N (2012). Use of laccase in pulp and paper industry. Biotechnology progress, 28(1), 21-32.
Viswanath B, Rajesh B, Janardhan A, Kumar A P \& Narasimha G (2014). Fungal laccases and their applications in bioremediation. Enzyme research, 1-21.

Wang W, Liu F, Jiang Y, Wu G, Guo L, Chen R \& Xie B (2015). The multigene family of fungal laccases and their expression in the white rot basidiomycete

Flammulina velutipes. Gene 563(2), 142-149.

Yamauchi M, Sakamoto M, Yamada M, Hara H, Taib S M, Rezania S \& Hanafi FHM (2018). Cultivation of oyster mushroom (Pleurotus ostrreatus) on fermented moso bamboo sawdust. Journal of King Saud UniversityScience 179 (1-2), 129-134.

Zeng X, Cai Y, Liao X, Zeng X, Li W \& Zhang D (2011). Decolorization of synthetic dyes by crude laccase from a newly isolated Trametes trogii strain cultivated on solid agro-industrial residue. Journal of Materials 187(1-3), 517-525. 